\title{
What determines the success of economic transition? Constructing regional advantage for Eastern and Western European regions
}

\author{
KORNELIUSZ PYLAK ${ }^{3 *}$ (), ELŻBIETA WOJNICKA-SYCZ ${ }^{1,2}$ (1) and \\ PIOTR SYCZ ${ }^{1}$ (D)
}

${ }^{1}$ Department of Management, Gdansk University, Gdansk, Poland

${ }^{2}$ Department of Urban Design and Regional Planning, Faculty of Architecture, Gdansk University of Technology, Gdansk, Poland

${ }^{3}$ Department of Economic and Regional Policy, Faculty of Economics, Marie Curie Sklodowska University, Lublin, Poland

Received: March 23, 2018 • Revised manuscript received: July 18, 2018 • Accepted: September 19, 2018

(C) 2020 Akadémiai Kiadó, Budapest

\begin{abstract}
The aim of this paper is to identify the differences in the determinants of successful transition (understood as the creation of a new development path) between the eastern and the western EU Member States between 1994 and 2014 and elaborate assumptions for a strategy of constructing regional advantage for them at the NUTS2 level. We find that the regional transition requires individual approaches to using comparative advantage at the beginning of the process and then competing with specific advantages that can be consciously constructed throughout the process. Therefore, we hypothesise that a successful transition requires constructing regional advantages based on the knowledge-related factors, leading to specialisation in the knowledge-intensive industries. Furthermore, we state that the way of constructing such advantages differs across the regions. All of our hypotheses were confirmed. Both groups of regions had different comparative advantages at the beginning of the period and constructed competitive advantage based on related knowledge-intensive industries, leading to their specialisation. Interestingly, although the process of building regional advantage was similar, the factors used to create it were different, had a different impact on GDP growth and led to a different specialisation.
\end{abstract}

* Corresponding author. Department of Economic and Regional Policy, Faculty of Economics, Marie Curie Sklodowska University, Pl. M. Curie-Sklodowskieg 5, 20-031 Lublin, Poland. E-mail: korneliusz.pylak@gmail.com 


\section{KEYWORDS}

transformation, transition, development path, constructed advantage, regional development, innovation

\section{JEL CLASSIFICATION INDICES}

021, 031, R11

\section{INTRODUCTION}

There are many examples of the crucial role of regional innovation in successful transitions of regions found in literature, such as the Pomeranian and Lower Silesian regions in Poland (Wojnicka-Sycz 2018; Peszat - Szlachta 2017) or Brandenburg in Germany and Friuli Venezia Giulia in Italy (Dąbrowska 2017; Wojnicka-Sycz 2017). The measures of regional innovation policies that were introduced in these regions referred to a strategic thinking, the creation of proinnovative infrastructure, such as science and technology parks, R\&D grants, and the promotion of innovative networks and clusters. Regions - as defined in the European Union NUTS2 system - need to increase both sales and production opportunities. Sales opportunities are dependent on both the internal market size characterised by purchasing power of the inhabitants and openness to external markets. Openness to external markets gives great opportunities and usually causes growth of the weaker areas (Ades - Glaeser 1999; Csiki et al. 2019), but it can also be a threat when the weaker region is drained of resources and treated as a market for the inferior sort of goods by the stronger regions. Therefore, the weaker region must have the potential to keep its resources and produce competitive goods and services on the global market.

The ability to produce competitive goods and services can be a path to creating constructed regional advantage (Asheim - Moodysson et al. 2011). The advantage derives from the creation of unique products, and thus, specific product differentiation reflected in regional specialisations and clustering is crucial (Porter 1998). However, regional specialisation and spatial concentration of industries is not the only or sufficient condition for the success of the regional transition. The case of Hungary shows that regional specialisation did not induce growth and even lowered the productivity level and employment growth (Lengyel - Szakálné Kanó 2014).

The aim of the paper is to identify the differences in determinants of successful transition between the eastern and the western regions in the European Union (EU) and to elaborate assumptions for a strategy of constructing regional advantage for various regions. The paper contributes to the debate surrounding regional competitiveness in two ways: 1) by analysing the performance of the transition regions, that is, the regions changing their development paths through constructing regional advantages in order to achieve a quicker growth, and 2) investigating the differences between such regions and constantly developing regions on the one hand, and more- and less-developed regions on the other. Then, the analysis of the successful sources of transition regions will lay the foundation for building a precise and tailor-made strategy for such regions, making evidence-based policy happen. Therefore, the paper does not duplicate mechanisms elaborated for developed regions within the European policies (Asheim Moodysson et al. 2011). What is more, in the paper, we indicate the directions, which regional policy should follow in the long run, but we will not focus on the short-term aims and measures, leaving these issues for further research. 
The paper is organised as follows. Section 2 gives an account of the determinants of regional growth in general. Section 3 provides an overview of how regional competitiveness and regional advantage can be constructed, while Section 4 presents our hypotheses. Section 5 contains a description of the data used for this study and the empirical methodology. Section 6 conducts an empirical analysis and discussion of the differences between groups of regions indicating comparative and competitive advantages based on the real growth factors. Section 7 summarises major findings and makes a contribution to building the strategy of constructing regional advantages for the regions in transition.

\section{DETERMINANTS OF REGIONAL GROWTH}

Regional growth is dependent on internal and/or external demand and supply. In a seminal paper, Young (1928) asserted that a regional economy can grow with a constant population and without inventions until the demand ceases to be elastic and the returns cease to grow. Even though such a situation is just hypothetical, demand and supply play a key role in increasing GDP. In the case of one industry or product, high demand will stimulate more and more production, which will result in economies of scale, but on the other hand, the ever-increasing saturation of the market will force lower prices and lower marginal income thus diminishing further growth. However, in the case of the whole economy, companies can switch to other activities as the demand becomes inelastic or the returns are not satisfactory, and thus, growth would be sustained. Therefore, the purchasing power of the region's population and/or external markets seems to be crucial for the development of a regional economy and external markets are available for a region thanks to its openness (Ades - Glaeser 1999).

Openness can be measured in various ways, for example the share of export and import in whole sales of the region, location at the intersection of transport routes, or location close to a more developed region with a huge market. Availability of a huge market outside the region is a key, but not the only cause of its growth. In general, closeness to a highly developed region is important for the development of neighbouring areas because of the imbalances in the development level (Capello - Nijkamp 2009; Wojnicka-Sycz 2013b). These imbalances were a basis for creating the growth pole theory (Perroux 1950; Wojnicka-Sycz 2013a), the theory of polarized development (Hirschman 1958), the theory of cumulative causation (Myrdal 1968) and the centre-periphery theory (Friedmann - Weaver 1977). These theories indicate that the growth of the less-developed areas lacking connections to the strong centres or poles might be hampered. For the well-connected regions, the proximity of more developed regions provides the potential for exchange of goods, workers, capital, natural resources, and last but not least, knowledge.

\section{REGIONAL COMPETITIVENESS AND CONSTRUCTING REGIONAL ADVANTAGE}

Economic growth in the transition regions has to be greater than in other regions to experience convergence, therefore these regions have to gain advantage over other regions in some key areas. This advantage cannot be based only on the price or cost competition, because in the long-run this will drain regional potential. Competitiveness of the transition regions has to be 
built by optimising their assets to compete and prosper in the domestic and global markets (Porter 1990) with an invaluable role of knowledge and innovations. In other words, competitiveness means the ability to seize opportunities and minimize weaknesses through optimal use of all regional resources, especially human resources and knowledge. However, regional competitiveness is still an elusive concept (Kitson et al. 2004).

The literature emphasises three kinds of regional advantages: comparative, competitive and constructed advantage. Comparative advantage, popularised by Ricardo (1817: 85-103), means that countries produce and trade goods and services that are relatively more efficiently created than others. Although initial specialisation areas are of no importance in gaining a larger productivity level, and thus, higher comparative advantage, where changes of the structure in production over time are more likely to happen in more than less related industries (Hausmann - Klinger 2007). A related variety of industries is understood as a group of industries that exploit different but complementary pieces of knowledge (Asheim - Boschma et al. 2011).

Since specialisation of the transition regions should take place in related industries, an increase in shares of the related industries must be observed in the long term. In turn, at the beginning of the transition period, common knowledge must be present in a region for regional specialisations to flourish. Thus, in that sense comparative advantage can be seen mostly at the beginning of the period in terms of human resources and knowledge necessary to increase the productivity of the products and services to be specialised in. Such an approach is allowed because comparative advantage is perceived as a static phenomenon (Kitson et al. 2004).

Specialisation understood as an increase of a share of a given industry in sales or export is carried out in a highly competitive environment. Therefore, it must be related to the ability to constantly change and improve, and thus, the potential for dynamic progressiveness based on the optimal use of knowledge and innovations (Porter 1990). Although the comparative advantage of the transition regions in possessing knowledge is a sine qua non condition, it is not enough. The regions have to gain competitive advantage in technologically related sectors, between which knowledge spill-overs and learning opportunities induce innovativeness thus increasing productivity (Asheim - Boschma et al. 2011). Therefore, in general, the transition regions should specialise in knowledge-intensive industries like high-tech and medium-hightech manufacturing industries and knowledge-intensive services to develop a competitive advantage.

However, specialisation forcing changes in the structure of the economy occur spontaneously, hence the need to manage this change appeared in the last decade resulting in the introduction of the construction of a regional advantage (Asheim - Boschma et al. 2011). Constructing a regional advantage consists in turning comparative advantage into competitive advantage through a conscious platform policy based on related variety and differentiated knowledge bases with a significant interplay between the industrial and institutional dynamics and multi-level governance (Asheim - Moodysson et al. 2011). Thus, in fact these three types of advantages can interact with each other and can be cleverly used for building a regional development strategy.

Therefore, upon the above-mentioned theoretical foundation we can build the model of constructing regional advantage by the regions in transition (see Table 1). The model reflects the performance of these regions indicating the policy goals to be achieved to succeed in the transition process. The performance of the transition regions is referred to other reference regions to reflect the gain of the competitive advantage by these regions. However, the inverse 
Table 1. Theoretical dynamic model of constructing regional advantage by transition regions

\begin{tabular}{|c|c|c|c|c|}
\hline & \multicolumn{3}{|c|}{ Reference regions in the beginning of the period } \\
\hline & & $\begin{array}{c}\text { Higher than transition } \\
\text { regions }\end{array}$ & Similar as transition regions & Lower than transition regions \\
\hline \multirow{3}{*}{ 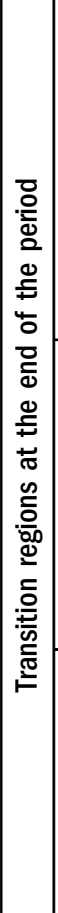 } & 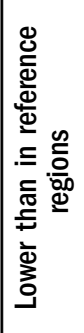 & $\begin{array}{c}(-) \\
\text { COMPARATIVE } \\
\text { ADVANTAGE } \\
\text { OF REFERENCE REGIONS }\end{array}$ & $\begin{array}{c}(--) \\
\text { CONSTRUCTING ADVANTAGE BY } \\
\text { REFERENCE REGIONS }\end{array}$ & $\begin{array}{c}(---) \\
\text { LOSS OF COMPARATIVE } \\
\text { ADVANTAGE BY TRANSITION } \\
\text { REGIONS AND CONSTRUCTING } \\
\text { ADVANTAGE BY REFERENCE } \\
\text { REGIONS } \\
7 .\end{array}$ \\
\hline & 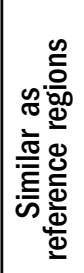 & $\begin{array}{c}(++) \\
\text { CONVERGENCE TO REFER- } \\
\text { ENCE REGIONS }\end{array}$ & $\begin{array}{c}(-/+) \\
\text { STATUS QUO }\end{array}$ & $\begin{array}{c}(--) \\
\text { LOSS OF COMPARATIVE } \\
\text { ADVANTAGE }\end{array}$ \\
\hline & 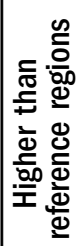 & $\begin{array}{c}(+++) \\
\text { CONSTRUCTING REGIONAL } \\
\text { ADVANTAGE FROM WORSE } \\
\text { POSITION } \\
\mathbf{3} .\end{array}$ & $\begin{array}{c}(++) \\
\text { CONSTRUCTING REGIONAL } \\
\text { ADVANTAGE FROM SIMILAR } \\
\text { POSITION } \\
\mathbf{2 .}\end{array}$ & $\begin{array}{c}(+) \\
\text { COMPARATIVE ADVANTAGE } \\
\text { OF TRANSITION REGIONS }\end{array}$ \\
\hline
\end{tabular}

process is also possible. Although at the beginning of the period, the transition regions might have comparative advantage based on input costs, location, resources, including cheap labour that persists over time (Porter 1998), in our model comparative advantage is based mostly on the knowledge that is necessary to gain a competitive advantage (path no. 1).

Then, the construction of regional advantage is gaining momentum, which is presented in Table 1 by $(+)$ signs. The construction of regional advantage can begin from different positions relative to the reference regions. As a result, we can observe different development paths (no. 1-4), visualised also in Fig. 1(a). The paths are based on elaborating an advantage during time $t+k$ comparing to the reference regions reflected by the higher growth of performance indicators, and thus, higher level of indicators than in the reference regions in the end of the analysed period.

If the transition regions are in a similar position at the beginning of the period, they can construct a regional advantage based on one of the factors, and thus, the value of the performance measure at the end of the period will be higher than in the reference regions (path no. 2). If the transition regions are in a worse position at the beginning of the period, they can both converge to the reference regions (path no. 4) or even surpass the reference regions in terms of 

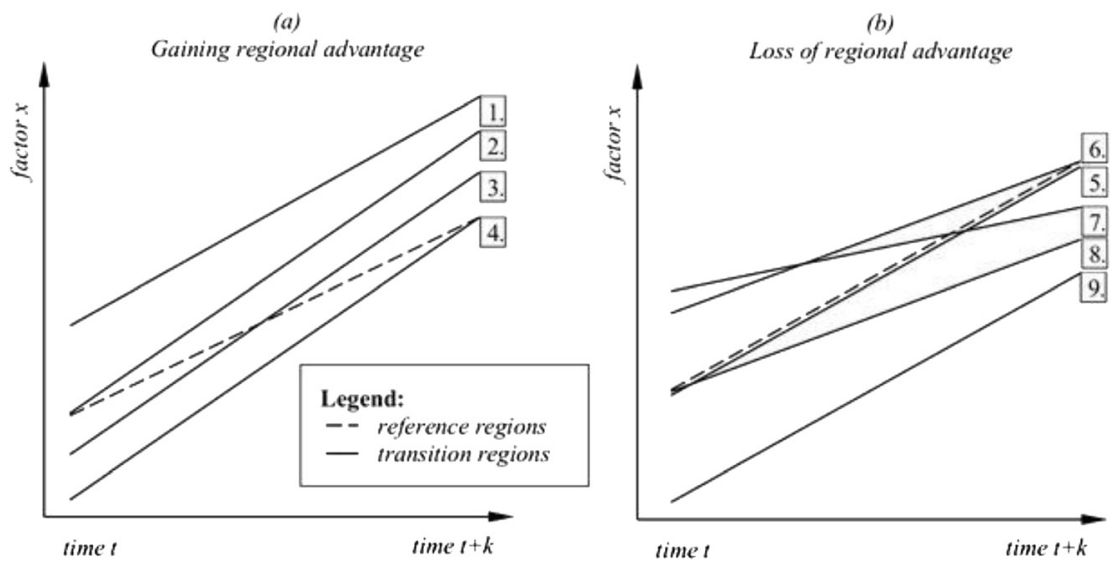

Figure 1. Possible paths of gaining and losing regional advantage by the transition regions referring to the reference regions

given performance measures (path no. 3). The latter development path is the most difficult to implement and requires the most resources and efforts $(+++)$.

On the other hand, the transition regions might not need to construct regional advantage in some of the development areas. Therefore, both groups of regions (transition and reference) can maintain the status quo (path no. 5) or even the reference regions might construct a competitive advantage over the transition regions (paths no. 6-9). In other words, these latter paths show which factors are not essential for the transition or which may even hamper the process of transition.

\section{OUR HYPOTHESES}

As outlined above, transition of the less developed regions, and thus, convergence requires a high growth level, which can be based on expanding the market area and production capabilities. Therefore, we can state the main hypothesis as:

Hypothesis 1 (H1): Most of the transition regions that succeeded in achieving high growth rates had constructed a regional advantage.

We assume that constructing a regional advantage is reflected by significant changes of knowledge-related factors in the transition regions comparing to other (reference) regions during the past decades. At the same time, other factors that are not essential for the transition process and success (not related to knowledge directly or indirectly) should be reduced to what can cause advantages for other regions (paths no. 5-9 on Fig. 1b).

The main hypothesis can be, however, described by two auxiliary hypotheses ( $\mathrm{H} 1 \mathrm{a}$ and $\mathrm{H} 1 \mathrm{~b}$ ). In the long run, regions can compete on the global market only by technological progress and increasing productivity since expansion of the population and workforce and exploiting natural resources have its limits (Uppenberg - Strauß 2010). Therefore, successful transition has to be based on knowledge resources that need to be present and achievable in a transition region 
before changes. It is very important since in the less-developed regions endogenous potential for growth is usually not sufficient to achieve a high level of development (Pylak - Majerek 2014b). What is more, the previous findings have revealed that the regions experiencing successful transitions had a much more knowledge-intensive workforce than other regions (Pylak 2015). An educated workforce is characterised by adequate learning skills and knowledge absorption abilities (Romer 1986; Lucas 1988) which are crucial for the upcoming transition processes. Thus, we can hypothesise:

Hypothesis 1a (H1a): Comparative advantage of the transition regions is based on knowledge in the majority of cases.

Hypothesis $1 \mathrm{~b}(\mathrm{H} 1 \mathrm{~b})$ : Competitive advantage of the transition regions leads to specialisation in knowledge-intensive industries in the majority of cases.

A significant number of scientific publications indicates distinct differences in characteristics of development paths between regions and countries (Zukauskaite - Moodysson 2016). In particular, factors influencing growth differ across more- and less-developed regions (see for example: Pylak - Majerek 2014a; Pylak - Majerek 2014b). Almost all eastern European regions could be characterised as less-developed in the 1990s, thus their development opportunities were different not only because they lack resources and potentials but also because their historical context was much different from the western regions. Although accession to the EU was perceived as an important trigger to change regional development paths, the transition process was not successful enough in general (Recher - Kurnoga 2017). Although the eastern regions encounter many obstacles in gaining a sufficient growth rate for convergence (Pylak 2015), the literature indicates individual cases of the eastern regions experiencing successful transition processes (see e.g. Pylak - Wojnicka-Sycz 2017) making the analysis of the eastern regions feasible and valuable for strategy planning. Therefore, we hypothesise that:

Hypothesis 2 (H2): Constructing advantages of the transition regions differs in the western and eastern regions. The eastern transition regions develop knowledge-related factors to a greater extent than the western regions.

The analysis was divided into those two groups of regions (the western European regions are located in the EU member states before 2004 and the eastern regions belong to the countries that joined the EU in 2004 and after) which would separate the impact of regional potential on the success of development process from the contextual and historical factors influencing growth. However, the factors that influencing growth may refer to both absorption potential and the level of regional development and this issue cannot be captured by the analysis. If the hypotheses are confirmed, we could draw recommendations for policymakers on constructing regional advantage in different regions to accelerate growth.

\section{DATA AND METHODS}

We use a proxy for the level of development as the level of GDP per capita and we measure the pace of growth using the GDP growth rate in absolute and relative terms. Both GDP per capita and the growth rate are measured in terms of purchasing power standard (PPS) so as to make performance compatible. Growth is a function of internal or external market size. Both markets are substitutes for each other because a region benefits from selling its products and services 
everywhere. The size of the internal market can be reflected by the initial wealth of the region and compensation of employees as demand factors and financial capital, and external market size can be reflected by its openness (Ades - Glaeser 1999). Therefore, to test Hypothesis 1 GDP per capita, compensation, population density and company density at the beginning of the period is used in the research as a proxy for both markets' size, including density indicators as a quantitative proxy for the size of the internal market.

Finally, constructing regional advantages requires changes in different economic and social indicators, particularly those related to knowledge and innovativeness according to Schumpeter (1934). These indicators refer to the labour market concerning gender structure, employment in science and technology, unemployment and compensation level, structure of R\&D expenditure, patent applications concerning knowledge-intensity and fixed capital expenditure. This set of indicators covers not only the regional absorption potential but also the availability, creation, absorption and diffusion of knowledge in the region (Pylak - Majerek 2014b). As a result of regional advantage, the structure of the economy may change concerning knowledge-intensity and the service sector. To gain the competitive advantage we assume that the gross value added will increase reflecting the productivity increase.

We also want to measure the impact of technological progress on constructing regional advantage according to Solow (1988), thus we introduced the technology advancement synthetic indicator (TASI) of a region $j$ calculated as in (1):

$$
\operatorname{TASI}_{j}=\frac{1}{n} \sum_{i=1}^{n} x_{i j}
$$

where $n$ is the number of single indicators included in the synthetic indicator, $\boldsymbol{x}_{i j}$ is the single indicator (i.e. $\langle<1, \ldots, n>$ ) for region $j$. The indicator is calculated for each region as the arithmetic average of the standardised values (thus the weights of single indicators are equal) in the beginning and the end of the analysed period of the following variables:

Share of employment in high-tech industries as \% of total employment;

Share of employment in knowledge-intensive high-tech services as \% of total employment;

Persons with tertiary education (according to the International Standard Classification of Education - ISCED) and share of human resources in science and technology core (HRSTC); Patent applications to the European Patent Office (EPO) per million inhabitants;

Business R\&D expenditures as \% of GDP (BERD).

The quality of the indicator is confirmed in line with the OECD (2008) by checking the Cronbach's alpha indicator measure of internal consistency, which achieved the satisfactory value of 0.76 . Moreover, the Keiser-Meyer-Olkin measure of sampling adequacy was calculated which also had a satisfactory value of 0.67 . Bartlett's test for homogeneity of variances allowed us to reject the null hypothesis at $P<0.001$ and conclude that at least one batch of variance is different than the other. Thus, it means that the above variables could constitute a single synthetic indicator. The correlation coefficients between single indicators were between 0.08 and 0.65 , thus the synthetic indicator captures mainly effects of single indicators and to a small extent common effects of correlated indicators (Becker et al. 2017). Despite the good fit and adequacy of the composite indicator, we should bear in mind its weaknesses and different 
reflections that the indicator can provide on technology advancement. Therefore, we also analyse single indicators included in TASI.

The analysis of the factors influencing growth in different groups of regions was based on available Eurostat data on the second level of Nomenclature of Units for Territorial Statistics (NUTS2). The complete data for these two periods was available for 40 eastern regions and 144 western regions. To test the hypothesis, we analysed separately the fast and slow growing regions in both western and eastern groups. The eastern fast-growing regions are the regions that reached GDP growth in PPS above the median for all analysed eastern regions (6,100 PPS) in the years 2000-2014 and improved their position in terms of GDP per capita in comparison with the most developed region (the benchmark). The western fast-growing regions are the regions with GDP growth over 30\% (with the median for the western analysed regions at 26\%) and absolute GDP growth over the median for the eastern regions (6,100 PPS). Therefore, such an approach allowed us to take into account both the strong regions with significant increase in terms of absolute values, as well as the regions with strong GDP growth without significant GDP base at the beginning of the period. To sum up, we divided the regions into four groups (see Fig. 2): 1) 22 Eastern regions with high GDP growth (eastern growing group, EGG); 2) 61 Western regions with high GDP growth (western growing group, WGG); 3) 18 Eastern regions with a constant GDP (eastern constant group, ECG); and 4) 83 Western regions with a constant GDP (western constant group, WCG). However, due to the lack of data for many regions it was impossible to use spatial econometric models.

Economic transitions do not happen quickly. Although statistical data availability is a meaningful constraint, we gathered data for a 20-year timespan (1994-2014), which is long enough for the transition processes to happen. To capture a change in the development path, the analysis was conducted for two periods: 1) at the beginning of the period - before entering the EU and receiving EU pre-accession funds (between 1994 and 2000) by the eastern regions; and 2 ) at the end of the period - after entering the EU but also skipping the apogee of the economic crisis in 2011-2014. Although Croatia entered the EU in 2013 as the last country, we couldn't take data only from 2014 because we wanted to ensure data stability, and thus, we took a 4-year average of the most up-to-date data (2011-2014).

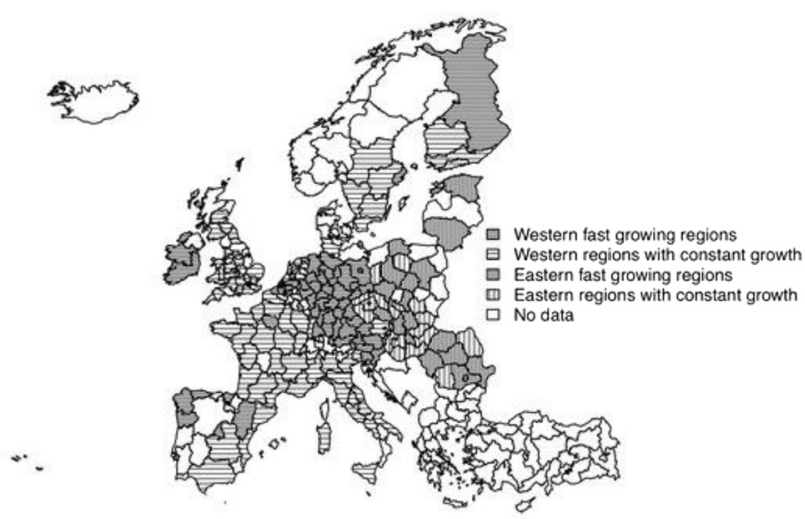

Figure 2. European regions under investigation with four groups indicated 
The variables were standardised, using equation (2), according to the distance to the benchmark (maximum value of the indicator) separately in 1994-2000 and 2011-2014:

$$
x_{i}=1-\frac{(-1)\left(z_{i}-\max _{z}\right)}{\left(\max _{z}-\min _{z}\right)}
$$

where $x_{i}$ is the standardised variable; $z_{i}$ is the original value of the variable $z$ for region $i$; and $\max _{z} / \min _{z}$ is the maximum/minimum value of variable $z$ for all analysed regions. The standardised variable shows the relative position of region $i$ concerning variable $z$ within the scale, in which 1 is the highest and 0 is the lowest value. We used standardisation to compare two different periods of time, and thus, we could analyse the change in relative position of the regions during the beginning and the end of the 1994-2014 period.

The change in relative position of the regions belonging to one of the groups may indicate that the given variable was important in accelerating growth rate in this group. However, to become a growth factor, the differences between the groups had to be statistically important. Therefore, the factors influencing growth were assigned to both of the eastern and the western regions with high GDP growth if the change of value of the given factor in comparison to the reference groups (ECG, WCG) was statistically significant. Supplementary comparison of means was conducted to indicate the differences in both western and eastern groups of regions between the fast-growing and steady-growing subgroups of regions. We applied a t-test, which is commonly used to determine if two independent data sets are significantly different.

Then, we ran econometric analysis to indicate knowledge-related factors influencing growth in the different groups of regions. Econometric analysis was performed using Ordinary Least Squares (OLS) and Instrumental Variables Method (IVM) with the usage of Two Stage Least Squares (2SLS) estimator. IVM was used because of the possible endogeneity of the technological advancement index in influencing growth in the group of all eastern and western regions. As instrumental variables were taken those resembling the initial potential in knowledgeintensive market services, other knowledge-intensive services and in medium-high-tech industries (standardised share of employment in 1994), as well as the share of economically active people with tertiary level education in the active population in 2014. Location of other more traditional but knowledge-intensive manufacturing and service industries can also be taken into account. Higher activity of tertiary educated people reflects the demand for scientists in technologically advanced activities and $\mathrm{R} \& \mathrm{D}$, which are included in the synthetic index. We used the Hausman test for exogeneity of the technological advancement index. The test results showed that the null hypothesis was not rejected $(P=0.17)$, so the OLS estimator was efficient and the technology advancement index was exogenous. According to Cameron - Trivedi (2009), this procedure may be used to confirm the causality relations between variables.

In one model we used a binary dependent variable indicating the growing regions (value of 1) with absolute growth of GDP 2000-2014 in PPS over 8,550 PPS, and 0 - otherwise. The model was estimated with logit regression (a logit model), which is used in the case of dichotomous outcome variables. Binary Logistic Regression is a specific type of regression where the binary response variable is related to a set of explanatory variables, including discrete and/or continuous variables. In the logit model, the log odds of the outcome are modelled as a linear combination of the predictor variables. Logit regressions show the probability that an explained variable will be 1 or 0 with given parameters and values of explanatory variables (3): 


$$
\operatorname{Prob}(\mathrm{Y}=1)=\mathrm{F}\left(\beta^{\prime} \mathbf{X}\right), \operatorname{Prob}(\mathrm{Y}=0)=1-\mathrm{F}\left(\beta^{\prime} \mathbf{X}\right),
$$

The set of structural parameters $\beta$ shows the impact of the explanatory variables $(\mathrm{X})$ on the explained variable (Y). The main disadvantage of the inference based on logit models is the complicated interpretation of its coefficients, as the estimates cannot be interpreted as a marginal increase of an explained variable caused by a unitary increase of a given explanatory variable. However, the marginal effects can be computed, for example by means of the regressors. The sign can be directly interpreted: the positive value of a parameter estimate means that an increase of a corresponding variable will increase the probability of the occurrence of a situation or feature described by the explained variable.

The estimated models are based on the hypothesis that GDP change in absolute and relative terms may depend on different growth factors. The linear models take the form of $\mathrm{Y}_{n}=\mathbf{X} \beta+\varepsilon$, while the logit model (Greene 2003) takes the form of (4):

$$
\mathrm{P}\left(\mathrm{Y}_{\mathrm{n}}=1 \mid \mathbf{X}\right)=\Lambda(\mathbf{X} \beta)=\frac{\exp (\mathbf{X} \beta)}{1+\exp (\mathbf{X} \beta)},
$$

where $\Lambda(X \beta)$ is a logistic cumulative distribution function, $\mathrm{Y}_{\mathrm{n}}$ is - depending on the model - absolute growth of GDP per capita in PPS, standardised in terms of the benchmark GDP per capita change in 2000-2014 or the dynamics of GDP 2014/2000, with $n=1, \ldots, N$ regions, $\mathbf{X}$ is a vector containing a set of growth factors, and $\beta$ is a vector of parameters. The growth factors are similar to those analysed in the comparison of means for particular groups of regions. Moreover, in the regression for all the European regions the binary variable indicates the location of a region in the eastern group (value 1) or western group (value 0$)$.

\section{EMPIRICAL RESULTS AND DISCUSSION}

To test the hypotheses stated in Section 4 we compared four groups of regions in three-ways. First, we compared the fast and slow growing western regions and the fast and slow growing eastern regions to find the factors within the main groups of regions (western and eastern) responsible for accelerating the growth indicating the comparative and constructed advantages. Thus, we could test the main hypothesis (H1) and auxiliary hypotheses ( $\mathrm{H} 1 \mathrm{a}$ and $\mathrm{H} 1 \mathrm{~b}$ ) in terms of the knowledge-driven factors. However, still an analysis of the impact of the knowledgedriven factors on regional growth is necessary to finally test both auxiliary hypotheses. Therefore, we ran logit regressions to indicate the impact of these factors on GDP growth in different groups of regions.

Comparing both mechanisms accelerating growth in the eastern and the western regions gives an input to test Hypothesis 2. However, the final testing of the hypothesis is made when comparing and indicating significant differences between these two groups. Identification of these differences is important to prepare regional development policies and measures focused on constructing regional advantages tailored to the specificity of different regions. These three comparisons are presented in Table 2. 
Table 2. Average values of factors describing development paths of the eastern and western fast- and slow-growing regions with significant differences between the groups of regions

\begin{tabular}{|c|c|c|c|c|c|c|c|c|c|c|}
\hline \multirow[b]{2}{*}{ Variable } & \multirow[b]{2}{*}{ Year } & \multicolumn{3}{|c|}{$\begin{array}{c}\text { East-west growing regions } \\
\text { comparison }\end{array}$} & \multicolumn{3}{|c|}{$\begin{array}{l}\text { West fast- and slow-growing } \\
\text { regions comparison }\end{array}$} & \multicolumn{3}{|c|}{$\begin{array}{l}\text { East fast- and slow-growing } \\
\text { regions comparison }\end{array}$} \\
\hline & & EGG & WGG & $P$ & WGG & WCG & $\boldsymbol{P}$ & EGG & ECG & $\boldsymbol{P}$ \\
\hline \multicolumn{11}{|l|}{ Labour market composition: } \\
\hline \multirow{2}{*}{$\begin{array}{l}\text { Number of business units per } \\
\text { inhabitant }\end{array}$} & 1999 & 38.73 & 21.06 & $* *$ & 21.06 & 41.60 & $* * *$ & 38.73 & 51.09 & \\
\hline & 2012 & 57.17 & 35.51 & $* *$ & 35.51 & 48.55 & $* * *$ & 57.17 & 55.46 & \\
\hline \multirow{2}{*}{$\begin{array}{l}\text { Share of employment in high- } \\
\text { tech industries as } \\
\text { percentage of total } \\
\text { employment }\end{array}$} & 1994 & 0.80 & 1.57 & $* * *$ & 1.57 & 1.58 & & 0.80 & 1.09 & \\
\hline & 2013 & 1.32 & 1.51 & & 1.51 & 1.11 & $* *$ & 1.32 & 1.60 & \\
\hline \multirow{2}{*}{$\begin{array}{l}\text { Share of employment in } \\
\text { medium-high-tech } \\
\text { industries as percentage of } \\
\text { total employment }\end{array}$} & 1994 & 5.76 & 4.80 & $*$ & 4.80 & 5.89 & $*$ & 5.76 & 6.40 & \\
\hline & 2013 & 5.34 & 6.16 & & 6.16 & 3.69 & $* * *$ & 5.34 & 7.13 & \\
\hline \multirow{2}{*}{$\begin{array}{l}\text { Share of employment in } \\
\text { medium-low- and low-tech } \\
\text { industries as percentage of } \\
\text { total employment }\end{array}$} & 1994 & 16.62 & 8.30 & $* * *$ & 8.30 & 13.27 & $* * *$ & 16.62 & 18.14 & \\
\hline & 2013 & 13.80 & 9.82 & $* * *$ & 9.82 & 9.06 & & 13.80 & 14.99 & \\
\hline \multirow{2}{*}{$\begin{array}{l}\text { Share of employment in high- } \\
\text { tech knowledge-intensive } \\
\text { services as percentage of } \\
\text { total employment }\end{array}$} & 1994 & 2.83 & 2.41 & & 2.41 & 2.88 & $* *$ & 2.83 & 2.17 & $*$ \\
\hline & 2013 & 2.96 & 2.68 & & 2.68 & 2.82 & & 2.96 & 1.55 & $*$ \\
\hline \multirow{2}{*}{$\begin{array}{l}\text { Share of employment in } \\
\text { knowledge intensive market } \\
\text { services as percentage of } \\
\text { total employment }\end{array}$} & 1994 & 4.11 & 5.24 & $*$ & 5.24 & 6.34 & $* *$ & 4.11 & 2.92 & $*$ \\
\hline & 2013 & 5.00 & 5.87 & & 5.87 & 6.65 & $*$ & 5.00 & 3.51 & $*$ \\
\hline
\end{tabular}


Table 2. Continued

\begin{tabular}{|c|c|c|c|c|c|c|c|c|c|c|}
\hline \multirow[b]{2}{*}{ Variable } & \multirow[b]{2}{*}{ Year } & \multicolumn{3}{|c|}{$\begin{array}{l}\text { East-west growing regions } \\
\text { comparison }\end{array}$} & \multicolumn{3}{|c|}{$\begin{array}{l}\text { West fast- and slow-growing } \\
\text { regions comparison }\end{array}$} & \multicolumn{3}{|c|}{$\begin{array}{l}\text { East fast- and slow-growing } \\
\text { regions comparison }\end{array}$} \\
\hline & & EGG & WGG & $P$ & WGG & WCG & $P$ & EGG & ECG & $\boldsymbol{P}$ \\
\hline \multirow{2}{*}{$\begin{array}{l}\text { Share of employment in other } \\
\text { knowledge-intensive } \\
\text { services as percentage of } \\
\text { total employment }\end{array}$} & 1994 & 13.92 & 14.66 & & 14.66 & 19.25 & $* * *$ & 13.92 & 13.61 & \\
\hline & 2013 & 21.01 & 28.00 & $* * *$ & 28.00 & 30.38 & $* *$ & 21.01 & 22.54 & \\
\hline \multirow{2}{*}{$\begin{array}{l}\text { Share of employment in less- } \\
\text { knowledge-intensive } \\
\text { services as percentage of } \\
\text { total employment }\end{array}$} & 1994 & 20.18 & 15.06 & $*$ & 15.06 & 22.51 & $* * *$ & 20.18 & 20.50 & \\
\hline & 2013 & 24.90 & 26.90 & $*$ & 26.90 & 26.83 & & 24.90 & 22.92 & \\
\hline \multirow{2}{*}{$\begin{array}{l}\text { Employment rates of females } \\
\text { aged } 15-64 \text { year }\end{array}$} & 1999 & 56.34 & 55.89 & & 55.89 & 55.37 & & 56.34 & 52.55 & $*$ \\
\hline & 2014 & 57.06 & 66.81 & $* * *$ & 66.81 & 61.42 & $* * *$ & 57.06 & 56.02 & \\
\hline \multirow[t]{2}{*}{ Total unemployment rate } & 1999 & 9.08 & 7.87 & & 7.87 & 8.96 & & 9.08 & 9.66 & \\
\hline & 2014 & 8.15 & 6.70 & & 6.70 & 9.85 & $* * *$ & 8.15 & 8.09 & \\
\hline \multirow{2}{*}{$\begin{array}{l}\text { Long-term unemployment rate } \\
\text { in total unemployment }\end{array}$} & 1999 & 43.75 & 46.08 & & 46.08 & 36.56 & $* * *$ & 43.75 & 42.01 & \\
\hline & 2014 & 45.65 & 41.26 & & 41.26 & 40.92 & & 45.65 & 45.45 & \\
\hline \multicolumn{11}{|c|}{ People for science and technology: } \\
\hline \multirow{2}{*}{$\begin{array}{l}\text { Share of tertiary educated } \\
\text { active people in total } \\
\text { economically active people }\end{array}$} & 1999 & 15.32 & 22.55 & $* * *$ & 22.55 & 20.81 & & 15.32 & 10.43 & $*$ \\
\hline & 2013 & 28.52 & 30.99 & & 30.99 & 31.90 & & 28.52 & 20.07 & $* *$ \\
\hline \multirow{2}{*}{$\begin{array}{l}\text { Share of persons employed in } \\
\text { science and technology as } \\
\text { percentage of total active } \\
\text { population (HRSTO) }\end{array}$} & 1999 & 22.27 & 27.17 & $* *$ & 27.17 & 24.55 & $* *$ & 22.27 & 19.79 & \\
\hline & 2013 & 27.59 & 34.26 & $* * *$ & 34.26 & 31.21 & $* *$ & 27.59 & 23.41 & $*$ \\
\hline
\end{tabular}

(continued) 
Table 2. Continued

\begin{tabular}{|c|c|c|c|c|c|c|c|c|c|c|}
\hline \multirow[b]{2}{*}{ Variable } & \multirow[b]{2}{*}{ Year } & \multicolumn{3}{|c|}{$\begin{array}{c}\text { East-west growing regions } \\
\text { comparison }\end{array}$} & \multicolumn{3}{|c|}{$\begin{array}{l}\text { West fast- and slow-growing } \\
\text { regions comparison }\end{array}$} & \multicolumn{3}{|c|}{$\begin{array}{l}\text { East fast- and slow-growing } \\
\text { regions comparison }\end{array}$} \\
\hline & & EGG & WGG & $P$ & WGG & WCG & $P$ & EGG & ECG & $\boldsymbol{P}$ \\
\hline \multirow{2}{*}{$\begin{array}{l}\text { Share of tertiary educated } \\
\text { persons (ISCED) employed } \\
\text { in science and technology } \\
\text { as percentage of active } \\
\text { population (HRSTC) }\end{array}$} & 1999 & 10.10 & 14.11 & $* * *$ & 14.11 & 13.81 & & 10.10 & 7.27 & $*$ \\
\hline & 2013 & 18.45 & 20.24 & & 20.24 & 19.06 & & 18.45 & 13.22 & $* *$ \\
\hline \multicolumn{11}{|l|}{ Innovative performance: } \\
\hline \multirow{2}{*}{$\begin{array}{l}\text { R\&D expenditure as a } \\
\text { percentage of GDP }\end{array}$} & 2001 & 0.73 & 2.07 & $* * *$ & 2.07 & 1.64 & $*$ & 0.73 & 0.59 & \\
\hline & 2011 & 1.06 & 2.39 & $* * *$ & 2.39 & 1.86 & $*$ & 1.06 & 0.79 & \\
\hline \multirow{2}{*}{$\begin{array}{l}\text { Share of intramural R\&D } \\
\text { expenditure of business } \\
\text { sector in total R\&D (BERD) }\end{array}$} & 2000 & 53.12 & 66.28 & $*$ & 66.28 & 58.73 & $*$ & 53.12 & 52.95 & \\
\hline & 2011 & 43.40 & 65.15 & $* * *$ & 65.15 & 60.36 & & 43.40 & 52.95 & \\
\hline \multirow{2}{*}{$\begin{array}{l}\text { Share of intramural R\&D } \\
\text { expenditure of higher } \\
\text { education in total R\&D } \\
\text { (HERD) }\end{array}$} & 2001 & 24.10 & 23.66 & & 23.66 & 30.45 & $*$ & 24.10 & 30.54 & \\
\hline & 2011 & 31.71 & 22.92 & $*$ & 22.92 & 28.92 & $*$ & 31.71 & 34.62 & \\
\hline \multirow{2}{*}{$\begin{array}{l}\text { Share of intramural R\&D } \\
\text { expenditure of government } \\
\text { in total R\&D (GOVERD) }\end{array}$} & 2001 & 21.38 & 11.15 & $* * *$ & 11.15 & 12.10 & & 21.38 & 16.20 & \\
\hline & 2011 & 23.80 & 11.78 & $* * *$ & 11.78 & 9.85 & & 23.80 & 14.05 & \\
\hline \multirow{2}{*}{$\begin{array}{l}\text { Patent applications to the } \\
\text { EPO per million inhabitants }\end{array}$} & 2000 & 5.91 & 210.54 & $* * *$ & 210.54 & 103.93 & $* * *$ & 5.91 & 3.18 & \\
\hline & 2010 & 8.34 & 125.48 & $* * *$ & 125.48 & 48.88 & $* * *$ & 8.34 & 5.62 & \\
\hline \multirow{2}{*}{$\begin{array}{l}\text { Technological advancement } \\
\text { synthetic index (TASI) }\end{array}$} & 1994 & 0.16 & 0.29 & $* * *$ & 0.29 & 0.27 & & 0.16 & 0.12 & \\
\hline & 2011 & 0.20 & 0.30 & $* * *$ & 0.30 & 0.23 & $* * *$ & 0.20 & 0.14 & $*$ \\
\hline
\end{tabular}


Table 2. Continued

\begin{tabular}{|c|c|c|c|c|c|c|c|c|c|c|}
\hline \multirow[b]{2}{*}{ Variable } & \multirow[b]{2}{*}{ Year } & \multicolumn{3}{|c|}{$\begin{array}{c}\text { East-west growing regions } \\
\text { comparison }\end{array}$} & \multicolumn{3}{|c|}{$\begin{array}{l}\text { West fast- and slow-growing } \\
\text { regions comparison }\end{array}$} & \multicolumn{3}{|c|}{$\begin{array}{l}\text { East fast- and slow-growing } \\
\text { regions comparison }\end{array}$} \\
\hline & & EGG & WGG & $\boldsymbol{P}$ & WGG & WCG & $\boldsymbol{P}$ & EGG & ECG & $P$ \\
\hline \multicolumn{11}{|l|}{ Regional economy performance: } \\
\hline \multirow[t]{3}{*}{ GDP per capita in PPS } & 2000 & 10,755 & 22,693 & $* * *$ & 22,693 & 21,285 & & 10,755 & 8,888 & \\
\hline & 2011 & 20,100 & 30,967 & $* * *$ & 30,967 & 25,177 & $* * *$ & 20,100 & 13,761 & $*$ \\
\hline & 2014 & 22,859 & 34,082 & $* * *$ & 34,082 & 27,089 & $* * *$ & 22,859 & 17,022 & $*$ \\
\hline GDP growth per 1 inhabitant & $2014 / 2000$ & 229.90 & 146.24 & $* * *$ & 146.24 & 123.31 & $* * *$ & 229.90 & 173.03 & $* * *$ \\
\hline \multirow{2}{*}{$\begin{array}{l}\text { Gross value added at basic } \\
\text { prices in euro per } 1 \\
\text { employee in manufacturing } \\
\text { industries }\end{array}$} & 2000 & 10,928 & 54,655 & $* * *$ & 54,655 & 52,678 & & 10,928 & 9,854 & \\
\hline & 2011 & 29,548 & 88,670 & $* * *$ & 88,670 & 67,808 & $* *$ & 29,548 & 23,961 & \\
\hline \multirow{2}{*}{$\begin{array}{l}\text { Gross value added at basic } \\
\text { prices in euro per } 1 \\
\text { employee in wholesale and } \\
\text { retail trade, transportation, } \\
\text { accommodation, ICT }\end{array}$} & 2000 & 14,973 & 35,785 & $* * *$ & 35,785 & 42,843 & $* * *$ & 14,973 & 10,052 & $* * *$ \\
\hline & 2011 & 22,342 & 47,904 & $* * *$ & 47,904 & 51,102 & & 22,342 & 17,178 & $*$ \\
\hline \multirow[t]{2}{*}{ Compensation per employee } & 2000 & 6,729 & 25,974 & $* * *$ & 25,974 & 26,134 & & 6,729 & 6,226 & \\
\hline & 2011 & 12,824 & 32,574 & $* * *$ & 32,574 & 32,587 & & 12,824 & 11,302 & \\
\hline \multirow{2}{*}{$\begin{array}{l}\text { Gross fixed capital formation } \\
\text { per person employed }\end{array}$} & 2004 & 3,701 & 11,182 & $* * *$ & 11,182 & 11,440 & & 3,701 & 3,521 & \\
\hline & 2011 & 6,068 & 12,879 & $* * *$ & 12,879 & 11,578 & & 6,068 & 5,202 & \\
\hline
\end{tabular}

Source: Own elaboration based on Eurostat data.

Note: $P$ stands for significance of differences between group averages. Significance level: $0 * * * 0.001 * * 0.01 * 0.05$. Numbers of regions in each group are as follows: WGG: 61 , WC0: 83, EGG: 22, ECO: 18. 


\subsection{Constructing regional advantages in the more- and less-developed regions}

Table 2 presents the comparisons of both western and eastern regions with a high and constant growth. We can see that both groups of the western and eastern regions differ in terms of the changes of individual factors. Interestingly, in the western regions the changes are more intense than in the eastern regions but some of them reflect advantages of the slowly-growing western regions, while in the eastern regions advantages are only gained by the highly growing regions, except employment rate of females. In both comparisons, changes during the analysed period of time are various indicating different paths (see Table 1 and Fig. 1) which is discussed in detail in Section 6.3.

First, we analyse the developed regions in terms of comparative advantages at the beginning of the period and competitive advantages constructed during the studied time period. The WGG has comparative advantage over the WCG based on the innovative factors concerning higher share of persons employed in science and technology and higher R\&D expenditures, especially those incurred by the business sector. The WGG is also a leader in patenting new inventions. However, at the beginning of the period, an extraordinary innovative activity does not translate into significantly higher productivity in manufacturing industries, and in the service industries the productivity is even much lower than in the WCG.

Interestingly, during the analysed period both groups were changing their economic structure. The WGG was experiencing industrialisation of the medium-high-tech, medium-low and low-tech industries with constant share of high-tech industries, while the WCG was deindustrialising their economy. The WCG is service-based to a greater extent than the WGG, although the latter covers the gap in the case of the high-tech knowledge-intensive and lessknowledge-intensive services. Both the WGG and WCG developed their local markets by increasing the number of business units per inhabitant, although the WGG still has significantly less density of companies than the WCG.

The WGG used comparative advantage based on knowledge and innovations to construct successful development policy resulting in specialisation in the knowledge-intensive manufacturing industries supported by the service sector, significant growth of technological advancement and growth of productivity in both manufacturing and service sectors. Growth of productivity in the WGG is a key factor of GDP growth resulting in much higher GDP per capita in the end of the period compared to the WCG. The latter group was also increasing its investments in R\&D, employment in science and technology based on tertiary educated people but the results of productivity and GDP growth are not so spectacular as in the WGG. Therefore, the WCG also developed a knowledge-based economy but lost to competition in terms of knowledge transformation into productivity growth.

Comparative advantage of the eastern regions was built on tertiary educated people for science and technology and the share of knowledge-intensive high-tech and market services. The higher share of women employed is also noticeable. The eastern growing group (EGG) as much more specialised in these kinds of services than the eastern constant group (ECG), and thus, achieved higher productivity in the service sector even at the beginning of the period. However, we cannot omit manufacturing industries of the EGG increasing their share in the economy and productivity, although the increase is not significantly higher than in the ECG. Constructing regional advantage was based on increasing the technological advancement level (TASI) like in the WGG but the increase of productivity concerns the service sector to a significantly greater extent than the manufacturing sector. 


\subsection{Econometric analysis of growth factors in the regions}

After we found differences between fast- and steady-growing regions in the Western and the Eastern Europe, we tested whether growth factors referred to knowledge. Table 3 presents coefficients of OLS, 2SLS and logit models for all western and eastern regions, including the region with high growth. The analysis shows that dynamics of GDP was higher in the eastern regions than in the western regions. The models confirmed existence of many factors influencing growth in both groups of regions.

We confirmed the crucial importance of technological progress measured by the synthetic indicator (TASI) and its component variables in all the groups of the regions. We can see that the greater the change of technological advancement of a region between 1994 and 2013, the higher is the change of its GDP per inhabitant in PPS in 2000-2014. With IVM we also confirmed the causal and positive relation between technological advancement and GDP dynamics. Thus, this finding is in line with the neoclassical and new growth theories (Solow 1988; Romer 1986), in which technological progress reflected by R\&D intensity, share of employment in knowledge-intensive industries, HRSTC, and EPO patent applications are the main long-run growth factors. Moreover, the increase of the government's share in R\&D expenditure between 2000 and 2011 was correlated with the higher dynamics of GDP in the regions in 2000-2014, which indicates that technological advancement was partially successful due to the public technological policies.

However, technological advancement was not the main growth factor as it influenced growth mostly in an indirect way. We can see that an increase of the productivity in service industries like trade, transport, accommodation and information and telecommunication, was a more important growth factor than TASI. Interestingly, this factor was extremely important in the eastern regions, thus confirming the role of knowledge transfer in the highly growing group, which specialises in the knowledge-intensive services (see Section 6.1).

Transfer of technology can be reflected also by the outlays on fixed capital in the form of equipment and machines according to both classical and Keynesian growth theory (Keynes 1936; Ricardo 1817; Smith 1776). Increase in outlays on fixed capital in manufacturing industries in 2004-2011 is indeed positively correlated with the dynamics of GDP in all regions. However, technology transfer in the form of machines and equipment is a weaker growth factor than more creative, research-based technological development reflected by the technological advancement index.

After we investigated all the regions, we could look closer at the growth factors in the western regions (see Table 3). Logit regression shows that a significant growth of GDP per capita is more likely to happen in the regions with higher increase of the technological advancement index, higher increase of female employment rate, higher share of business in R\&D in a region at the beginning of the period and higher population density in 2013. The latter variable reflects agglomeration economies, and thus, greater markets. Interestingly, in the western regions GDP growth was caused not only by an increase of the share of governmental expenditures, but also enterprise expenditures in total R\&D expenditures.

For the growing western regions, the most significant factors of GDP per capita growth towards the benchmark in 2000-2014 were those referring to the productivity in transport, trade and ICT, similarly for all the regions. Therefore, despite the fact that the western regions achieved the greatest difference in productivity in manufacturing industries (see Table 2), 
Table 3. Econometric models of growth factors in the western and the eastern regions, including the fast-growing regions

\begin{tabular}{|c|c|c|c|c|c|c|}
\hline \multirow[b]{2}{*}{ Variable } & \multicolumn{2}{|c|}{$\begin{array}{c}\text { All eastern and western } \\
\text { regions }\end{array}$} & \multirow[b]{2}{*}{$\begin{array}{l}\text { All western regions } \\
\text { Logit ( } n=139 \text { ) } \\
\text { Change of GDP per } \\
\text { capita } 2014 / 2000 \\
\text { over } 8,550 \text { PPS }\end{array}$} & \multirow[b]{2}{*}{$\begin{array}{c}\text { WGG } \\
\text { OLS ( } n=42 \text { ) } \\
\text { Change of GDP per } \\
\text { capita in PPS } \\
\text { standardised in } \\
\text { terms of } \\
\text { benchmark }\end{array}$} & \multirow[b]{2}{*}{$\begin{array}{l}\text { All eastern regions } \\
\text { OLS ( } n=22 \text { ) } \\
\text { Change of GDP per } \\
\text { capita in PPS in } \\
\text { absolute values } \\
2010-2014 \text { (In) }\end{array}$} & \multirow[b]{2}{*}{$\begin{array}{c}\text { EGG } \\
\text { OLS }(n=14) \\
\text { Change of GDP per } \\
\text { capita in PPS } \\
\text { standardised in } \\
\text { terms of } \\
\text { benchmark }\end{array}$} \\
\hline & $\begin{array}{c}\text { OLS } \\
(n=101)\end{array}$ & $\begin{array}{c}2 S L S \\
(n=101)\end{array}$ & & & & \\
\hline Constant & $4.85^{* * *}$ & $-4.87 * * *$ & $-5.16 * * *$ & $-0.05 * * *$ & $8.14^{* * *}$ & -0.04 \\
\hline Eastern region & $0.23 * *$ & $0.20 * * *$ & & & & \\
\hline \multicolumn{7}{|l|}{ Labour market composition } \\
\hline $\begin{array}{l}\text { Standardised number of business } \\
\text { units per 1,000 inhabitants } \\
(2013)\end{array}$ & & & & & -0.30 & \\
\hline $\begin{array}{l}\text { Change of standardised number } \\
\text { of business units per } 1,000 \\
\text { inhabitants }\end{array}$ & & & & & $0.71 * *$ & \\
\hline $\begin{array}{l}\text { Standardised population density } \\
\text { (2013) }\end{array}$ & & & $3.57^{*}$ & & & \\
\hline $\begin{array}{l}\text { Employment share in high-tech } \\
\text { industries (1994) }\end{array}$ & & & & $-0.01 *$ & & \\
\hline $\begin{array}{l}\text { Change of standardised } \\
\text { employment share in medium- } \\
\text { high-tech industries (2013/ } \\
\text { 1994) }\end{array}$ & & & & $0.05 * * *$ & & \\
\hline
\end{tabular}


Table 3. Continued

\begin{tabular}{|c|c|c|c|c|c|c|}
\hline \multirow[b]{2}{*}{ Variable } & \multicolumn{2}{|c|}{$\begin{array}{l}\text { All eastern and western } \\
\text { regions }\end{array}$} & \multirow[b]{2}{*}{$\begin{array}{l}\text { All western regions } \\
\text { Logit ( } n=139) \\
\text { Change of GDP per } \\
\text { capita } 2014 / 2000 \\
\text { over } 8,550 \text { PPS }\end{array}$} & \multirow[b]{2}{*}{$\begin{array}{c}\text { WGG } \\
\text { OLS ( } n=42 \text { ) } \\
\text { Change of GDP per } \\
\text { capita in PPS } \\
\text { standardised in } \\
\text { terms of } \\
\text { benchmark }\end{array}$} & \multirow[b]{2}{*}{$\begin{array}{l}\text { All eastern regions } \\
\text { OLS ( } n=22 \text { ) } \\
\text { Change of GDP per } \\
\text { capita in PPS in } \\
\text { absolute values } \\
2010-2014 \text { (In) }\end{array}$} & \multirow[b]{2}{*}{$\begin{array}{c}\text { EGG } \\
\text { OLS ( } n=14 \text { ) } \\
\text { Change of GDP per } \\
\text { capita in PPS } \\
\text { standardised in } \\
\text { terms of } \\
\text { benchmark }\end{array}$} \\
\hline & $\begin{array}{c}\text { OLS } \\
(n=101)\end{array}$ & $\begin{array}{c}2 S L S \\
(n=101)\end{array}$ & & & & \\
\hline $\begin{array}{l}\text { Change of standardised } \\
\text { employment rate of women } \\
(2014 / 1999)\end{array}$ & $0.53^{* * *}$ & $0.44 * * *$ & $17.98 * * *$ & & & \\
\hline \multicolumn{7}{|l|}{ People for science and technology } \\
\hline $\begin{array}{l}\text { Change of standardised HRSTC } \\
(2013 / 1999)\end{array}$ & & & & $0.10 * * *$ & & \\
\hline \multicolumn{7}{|l|}{ Innovative performance } \\
\hline $\begin{array}{l}\text { Standardised share of R\&D in } \\
\text { GDP (2011) }\end{array}$ & & & & $0.07 * * *$ & & \\
\hline $\begin{array}{l}\text { Standardised business' share in } \\
\text { R\&D (2000) }\end{array}$ & & & $2.49 * *$ & & & \\
\hline $\begin{array}{l}\text { Change of standardised } \\
\text { government's share in R\&D } \\
(2011 / 00)\end{array}$ & $0.37 * * *$ & $0.36 * * *$ & & & & \\
\hline $\begin{array}{l}\text { Standardised patent applications } \\
\text { to the EPO per million } \\
\text { inhabitants }(2000)\end{array}$ & & & & $-0.06 * * *$ & & \\
\hline TASI (1994-2000) & & & & & $3.98 * * *$ & $0.22 * *$ \\
\hline
\end{tabular}




\begin{tabular}{|c|c|c|c|c|c|c|}
\hline \multirow[b]{2}{*}{ Variable } & \multicolumn{2}{|c|}{$\begin{array}{c}\text { All eastern and western } \\
\text { regions }\end{array}$} & \multirow[b]{2}{*}{$\begin{array}{l}\text { All western regions } \\
\text { Logit ( } n=139 \text { ) } \\
\text { Change of GDP per } \\
\text { capita } 2014 / 2000 \\
\text { over } 8,550 \text { PPS }\end{array}$} & \multirow[b]{2}{*}{$\begin{array}{c}\text { WGG } \\
\text { OLS ( } n=42 \text { ) } \\
\text { Change of GDP per } \\
\text { capita in PPS } \\
\text { standardised in } \\
\text { terms of } \\
\text { benchmark }\end{array}$} & \multirow[b]{2}{*}{$\begin{array}{l}\text { All eastern regions } \\
\text { OLS ( } n=22 \text { ) } \\
\text { Change of GDP per } \\
\text { capita in PPS in } \\
\text { absolute values } \\
2010-2014 \text { (In) }\end{array}$} & \multirow[b]{2}{*}{$\begin{array}{c}\text { EGG } \\
\text { OLS ( } n=14) \\
\text { Change of GDP per } \\
\text { capita in PPS } \\
\text { standardised in } \\
\text { terms of } \\
\text { benchmark }\end{array}$} \\
\hline & $\begin{array}{c}\text { OLS } \\
(n=101)\end{array}$ & $\begin{array}{c}\text { 2SLS } \\
(n=101)\end{array}$ & & & & \\
\hline Change of TASI & $0.23^{* *}$ & $0.62 *$ & $7.45^{*}$ & & 1.27 & -0.16 \\
\hline \multicolumn{7}{|l|}{ Regional economy performance } \\
\hline GDP per capita in PPS $(2000)$ & & & & & 0.00002 & \\
\hline $\begin{array}{l}\text { Change of standardised gross } \\
\text { value added per employee in } \\
\text { trade, transport, } \\
\text { accommodation, ICT (2011/ } \\
04 \text { ) }\end{array}$ & $0.74 * * *$ & $0.75^{* * *}$ & & $0.19 * *$ & $5.50 * * *$ & $0.91 * * *$ \\
\hline $\begin{array}{l}\text { Standardised outlays on fixed } \\
\text { assets (2004) }\end{array}$ & & & & & $-0.0001 * * *$ & \\
\hline $\begin{array}{l}\text { Change in standardised outlays } \\
\text { on fixed assets in } \\
\text { manufacturing industries } \\
(2011 / 2004)\end{array}$ & $0.16 * * *$ & $0.17 * * *$ & & $-0.07 * * *$ & & $0.43 * *$ \\
\hline $\begin{array}{l}\text { Change of standardised } \\
\text { compensation per employee } \\
(2011 / 2001)\end{array}$ & & & & $-0.41 * * *$ & & \\
\hline R-squared & 0.71 & 0.72 & $0.32^{a}$ & 0.82 & 0.91 & 0.94 \\
\hline
\end{tabular}


Table 3. Continued

\begin{tabular}{|c|c|c|c|c|c|c|}
\hline \multirow[b]{2}{*}{ Variable } & \multicolumn{2}{|c|}{$\begin{array}{c}\text { All eastern and western } \\
\text { regions }\end{array}$} & \multirow[b]{2}{*}{$\begin{array}{l}\text { All western regions } \\
\text { Logit ( } n=139) \\
\text { Change of GDP per } \\
\text { capita } 2014 / 2000 \\
\text { over } 8,550 \text { PPS }\end{array}$} & \multirow[b]{2}{*}{$\begin{array}{c}\text { WGG } \\
\text { OLS ( } n=42 \text { ) } \\
\text { Change of GDP per } \\
\text { capita in PPS } \\
\text { standardised in } \\
\text { terms of } \\
\text { benchmark }\end{array}$} & \multirow[b]{2}{*}{ 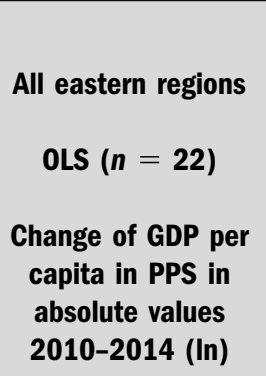 } & \multirow[b]{2}{*}{$\begin{array}{c}\text { EGG } \\
\text { OLS }(n=14) \\
\text { Change of GDP per } \\
\text { capita in PPS } \\
\text { standardised in } \\
\text { terms of } \\
\text { benchmark }\end{array}$} \\
\hline & $\begin{array}{c}\text { OLS } \\
(n=101)\end{array}$ & $\begin{array}{c}2 \text { 2SLS } \\
(n=101)\end{array}$ & & & & \\
\hline Hausman test $P$-value & - & 0.17 & - & - & - & - \\
\hline Sargan test $P$-value & - & 0.09 & - & - & - & - \\
\hline Test of normality of errors $P$-value & 0.44 & 0.74 & - & 0.64 & 0.89 & 0.92 \\
\hline $\begin{array}{l}\text { Ramsey's test of functional form } \\
P \text {-value }\end{array}$ & 0.17 & - & - & 0.69 & 0.92 & 0.82 \\
\hline Test for heteroscedasticity $P$-value & - & - & - & 0.70 & 0.65 & 0.25 \\
\hline
\end{tabular}

Source: Own calculations based on Eurostat data.

Notes: Significance level: See Table 2.

a In some cases, we used robust standard errors in the analyses; Instruments used in the model estimated with 2SLS: standardised employment share of other knowledge-intensive services in 1994, standardised employment share of knowledge intensive market services in 1994, standardised employment share of medium high-tech industry in 1994, share of tertiary educated active people in total economically active people 2014. McFadden's pseudo R-squared with $85 \%$ correctness of prediction (McFadden 1974). 
productivity growth in the service sector caused the real GDP growth, similarly to the eastern growing regions. The productivity growth may be brought about by increase in R\&D expenditures, increase of the share of people with tertiary education and employed in science and technology in the active population, and specialisation in medium-high-tech industries during 1994-2013. Interestingly, the share of high-tech industries in 1994 did not cause GDP growth, and thus, the WGG had a lower share of these industries in the economy during this period of time (see Table 2).

The fast-growing western regions are, hence, those with initially better position in technologically advanced activities which confirms the analysis in Section 6.1. However initial potential of EPO patent applications negatively impacts the increase of GDP per inhabitant. The negative relation can be caused by the fact that patents are not a good measure of innovative efforts and performance. Many technologically advanced activities, especially in services and industries with short product life cycles, do not result in application for patents. Also, we can see that an increase of outlays on fixed capital in manufacturing industries does not translate into GDP growth. This negative relation can be caused by both satisfactory capital equipment at the beginning of the period and a preference for spending money on $R \& D$, or the fact that productivity in the manufacturing sector is not a GDP growth factor.

The last negative growth factor refers to an increase of the compensation of employees, which can be caused by both the fact that in the beginning of the analysed period these regions already had high wages, or employees earning more but do not spend more, and thus, the market potential does not grow. However, the regions can expand their markets thanks to the openness to other regions.

The eastern regions can also increase their markets through both exploiting initial wealth of citizens (because GDP per capita in PPS in 2000 is a significant factor) and selling more to the local companies (because the change of number of businesses is a significant growth factor, too). The latter way of market expansion is most likely to happen as the eastern regions are specialised in knowledge-intensive services and such expertise is provided to other companies (Consoli Elche-Hortelano 2010), playing the role of knowledge carriers, producers and mediators, and thus, inducing innovativeness (Strambach 2008) and competitive advantage of the whole economy (Santos-Vijande et al. 2012) but especially in the service sector. An increase of productivity in the service sector is one of the most significant GDP growth factors. So, it is the initial level of the technological advancement index which indicates that the fastest growth is experienced by the regions with relatively high technological potential, which confirms the findings from Section 6.1. At the same time, the regions with high initial technological potential do not need to incur outlays on fixed assets as they require more sophisticated technology transfer or creation reflected by R\&D expenditures. However, in the manufacturing industries, growing outlays on fixed assets in 2004-2011 causes GDP growth indicating that in these industries buying machines and equipment is still the most effective technology transfer.

Econometric analysis conducted in this Section confirmed the results obtained in Section 6.1. Differences between groups indicate in the majority of cases the growth factors that need to be supported when constructing regional advantages. Also, the hypotheses concerning the role of knowledge and innovativeness in comparative advantage, and then, in transforming it into competitive advantage has been proved. Therefore, we can summarise the findings and elaborate policies tailored to different regions. 


\subsection{Policies on constructing regional advantages in different regions}

The results obtained in previous sections confirm that the western and the eastern transition regions construct their advantages in a completely different way, however, both approaches are based on comparative advantages of knowledge exploitation in the beginning of the transition period. Comparison of the WGG and EGG presented in Table 2 indicates many significant differences between the development paths of these regions. The WGG is still more developed than the EGG with higher GDP per capita, compensation per employee, gross fixed capital formation per person employed, and even, gross value added in the service industries. However, the EGG is able to use productivity in services to increase GDP to a greater extent than the WGG (Table 3). Throughout the analysis period, the WGG remains a leader in employing persons in science and technology, in technology advancement, including R\&D expenditures, especially those incurred by business sector, and patent applications. Despite the worse starting position, the western and the eastern growing groups lead in the share of employment in knowledge-intensive services and less-knowledge-intensive services, employment rate of females, and levels out in the share of employment in medium-high-tech industries.

On the other hand, the EGG maintains the advantage over the WGG concerning the number of business units per inhabitant, the share of employment in medium-low- and low-tech industries and levels out in the case of the share of employment in high-tech industries and knowledge intensive market services. The EGG is also a leader throughout the period in incurring $\mathrm{R} \& \mathrm{D}$ expenditures by the government and becomes a leader as far as higher education expenditure is concerned. The EGG develops tertiary education in an extraordinary way, including persons employed in science and technology, leading to the levelling of employment with the WGG.

This analysis definitely confirms different approaches and results of constructing regional advantages by the WGG and EGG. Therefore, we can focus on indicating the foundations of building policies for both groups separately. The foundations are built upon results from Sections 6.1 and 6.2. Tables 4 and 5 clearly present the paths (see Table 1 and Fig. 1) taken by the western and eastern fast-growing regions respectively compared to the reference regions referring to the individual factors. In addition, the bold factors influence GDP growth and the underlined factors indicate an inverse effect. Therefore, the emphasis should be placed on the bold factors in the lower and middle left fields of the matrix, while fields in the top and middle right can be discarded, unless the factors placed there are bold.

In the beginning of the transition, the western regions should have the comparative advantage of high R\&D expenditure, incurred mostly by business and governmental sectors which influences GDP growth. Patent activity is not necessary to gain GDP growth. A region needs to have people for science and technology, especially those who are tertiary educated and employed in science and technology, because then, GDP grows.

The structure of the economy should change in favour of the medium-high-tech industries which directly induce GDP growth. In turn, increasing the employment in the high-tech industries hampers GDP growth and increasing employment in the medium-low and low-tech industries and the service sector does not influence GDP growth. However, the service sector is very important as increasing productivity in this sector influences GDP growth positively.

During the transition of a region the following factors can be discarded: the share of higher education, $\mathrm{R} \& \mathrm{D}$ expenditure in total $\mathrm{R} \& \mathrm{D}$, share of employment in knowledge-intensive market 
Table 4. Dynamic changes of factors influencing and reflecting growth in WGG comparing to WCG

\begin{tabular}{|c|c|c|c|c|}
\hline & & \multicolumn{3}{|c|}{ The level of variable in the west regions with constant growth (WCG) at the beginning of the period } \\
\hline & & Higher than in WGG & Similar as in WGG & Lower than in WGG \\
\hline \multirow[t]{2}{*}{$\begin{array}{l}\text { The level of } \\
\text { variable in } \\
\text { the west } \\
\text { growing } \\
\text { regions } \\
\text { (WGG) at the } \\
\text { end of the } \\
\text { period is }\end{array}$} & $\begin{array}{c}\text { Lower than } \\
\text { in WCG }\end{array}$ & $\begin{array}{l}\text { MAINTAINING AN ADVANTAGE BY WCG } \\
\text { - Labour market composition: } \\
\text { O Share of employment in } \\
\text { knowledge-intensive mar- } \\
\text { ket and other services, } \\
\text { Number of business units } \\
\text { per inhabitant. } \\
\text { - Innovative performance: } \\
\text { Share of higher education } \\
\text { R\&D expenditure in total } \\
\text { R\&D. }\end{array}$ & $\begin{array}{l}\text { LOSS OF THE STATUS QUO BY WGG } \\
\text { - Labour market composition: } \\
\text { O Total unemployment rate. }\end{array}$ & $\begin{array}{l}\text { LOSS OF ADVANTAGE AND OVER- } \\
\text { TAKING BY WCG } \\
-\end{array}$ \\
\hline & $\begin{array}{r}\text { Similar as } \\
\text { in WCG }\end{array}$ & $\begin{array}{l}\text { ALIGNMENT TO THE WCG LEVEL } \\
\text { - Labour market composition: } \\
\text { O Share of employment in } \\
\text { medium-low- and low- } \\
\text { tech, } \\
\text { Share of employment in } \\
\text { high-tech knowledge- } \\
\text { intensive services, } \\
\text { Share of employment in } \\
\text { less-knowledge-intensive } \\
\text { services. }\end{array}$ & $\begin{array}{l}\text { MAINTAINING THE STATUS QUO } \\
\text { - People for science and tech- } \\
\text { nology: } \\
\text { O Share of tertiary educated } \\
\text { active people, } \\
\text { Share of tertiary educated } \\
\text { persons employed in sci- } \\
\text { ence and technology. } \\
\text { - Innovative performance: } \\
\text { Share of government } \\
\text { R\&D expenditure in total } \\
\text { R\&D. }\end{array}$ & $\begin{array}{l}\text { LOSS OF WGR ADVANTAGE } \\
\text { - Labour market composition: } \\
\text { Long-term unemployment } \\
\text { rate share in total unem- } \\
\text { ployment. } \\
\text { - Innovative performance: } \\
\text { Share of business R\&D } \\
\text { expenditure in total } \\
\text { R\&D. }\end{array}$ \\
\hline
\end{tabular}


Table 4. Continued

\begin{tabular}{|c|c|c|c|}
\hline & \multicolumn{3}{|c|}{ The level of variable in the west regions with constant growth (WCG) at the beginning of the period } \\
\hline & Higher than in WGG & Similar as in WGG & Lower than in WGG \\
\hline & $\begin{array}{l}\text { - Regional economy perfor- } \\
\text { mance } \\
\text { Gross value added per } \\
\text { employee in wholesale } \\
\text { and retail trade, trans- } \\
\text { portation, accommoda- } \\
\text { tion, ICT. }\end{array}$ & $\begin{array}{l}\text { - Economic economy perfor- } \\
\text { mance } \\
\text { Compensation per employee, } \\
\text { Gross fixed capital formation } \\
\text { per person employed. }\end{array}$ & \\
\hline $\begin{array}{l}\text { Higher } \\
\text { than in } \\
\text { WCG }\end{array}$ & $\begin{array}{l}\text { LOSS OF ADVANTAGE AND } \\
\text { OVERTAKING BY WGG } \\
\text { - Labour market composition: } \\
\text { Share of employment in } \\
\text { medium-high-tech in- } \\
\text { dustries. }\end{array}$ & $\begin{array}{l}\text { OVERTAKING WCO BY WGG } \\
\text { - Labour market composition: } \\
\text { Share of employment in } \\
\text { high-tech industries, } \\
\text { Employment rates of fe- } \\
\text { males aged 15-64. } \\
\text { - Innovative performance: } \\
\text { Technological advancement } \\
\text { synthetic index (TASI). } \\
\text { - Regional economy perfor- } \\
\text { mance } \\
\text { GDP per capita, } \\
\text { Gross value added per } \\
\text { employee in industry. }\end{array}$ & $\begin{array}{l}\text { MAINTAINING THE ADVANTAGE BY } \\
\text { WGG } \\
\text { - Innovative performance: } \\
\text { Share of persons } \\
\text { employed in science and } \\
\text { technology, } \\
\text { R\&D expenditure as a } \\
\text { percentage of GDP, } \\
\underline{\text { Patent applications to the }} \\
\underline{\text { EPO per million in- }} \\
\underline{\text { habitants. }}\end{array}$ \\
\hline
\end{tabular}


Table 5. Dynamic changes of factors influencing and reflecting growth in EGG comparing to ECG

\begin{tabular}{|c|c|c|c|c|}
\hline & \multicolumn{3}{|c|}{$\begin{array}{l}\text { The level of variable in the east regions with constant growth (ECG) } \\
\text { at the beginning of the period }\end{array}$} \\
\hline & & $\begin{array}{l}\text { Higher than in } \\
\text { EGG }\end{array}$ & Similar as in EGG & Lower than in EGG \\
\hline \multirow{2}{*}{$\begin{array}{l}\text { The level of variable } \\
\text { in the east } \\
\text { growing regions } \\
\text { at the end of the } \\
\text { period is }\end{array}$} & $\begin{array}{l}\text { Lower than } \\
\text { in ECG }\end{array}$ & $\frac{\text { MAINTAINING AN }}{\text { ADVANTAGE BY ECG- }}$ & $\underline{\text { LOSS OF THE STATUS QUO BY EGR- }}$ & LOSS OF ADVANTAGE AND OVERTAKING BY ECO- \\
\hline & $\begin{array}{l}\text { Similar as in } \\
\text { ECG }\end{array}$ & $\frac{\text { ALIGNMENT TO THE ECG }}{\text { LEVEL- }}$ & $\begin{array}{l}\frac{\text { MAINTAINING THE STATUS QU0 }}{\text { - Labour market composition: }} \\
\text { Number of business units per } \\
\text { inhabitant, } \\
\text { Share of employment in } \\
\text { manufacturing industries, } \\
\text { including high-tech, and me- } \\
\text { dium-high-tech, } \\
\text { Share of employment in other } \\
\text { knowledge-intensive services and } \\
\text { less-knowledge-intensive services, } \\
\text { Unemployment rate. } \\
\text { - Innovative performance: } \\
\text { R\&D expenditures, } \\
\text { Patent applications. } \\
\text { Regional economy performance: } \\
\text { Gross value added per employee in } \\
\text { industry, } \\
\text { Compensation per employee, } \\
\text { Gross fixed capital formation per } \\
\text { person employed. }\end{array}$ & $\begin{array}{l}\text { LOSS OF EGR ADVANTAGE } \\
\text { - Labour market composition: } \\
\text { Employment rates of } \\
\text { females aged 15-64. }\end{array}$ \\
\hline
\end{tabular}


Table 5. Continued

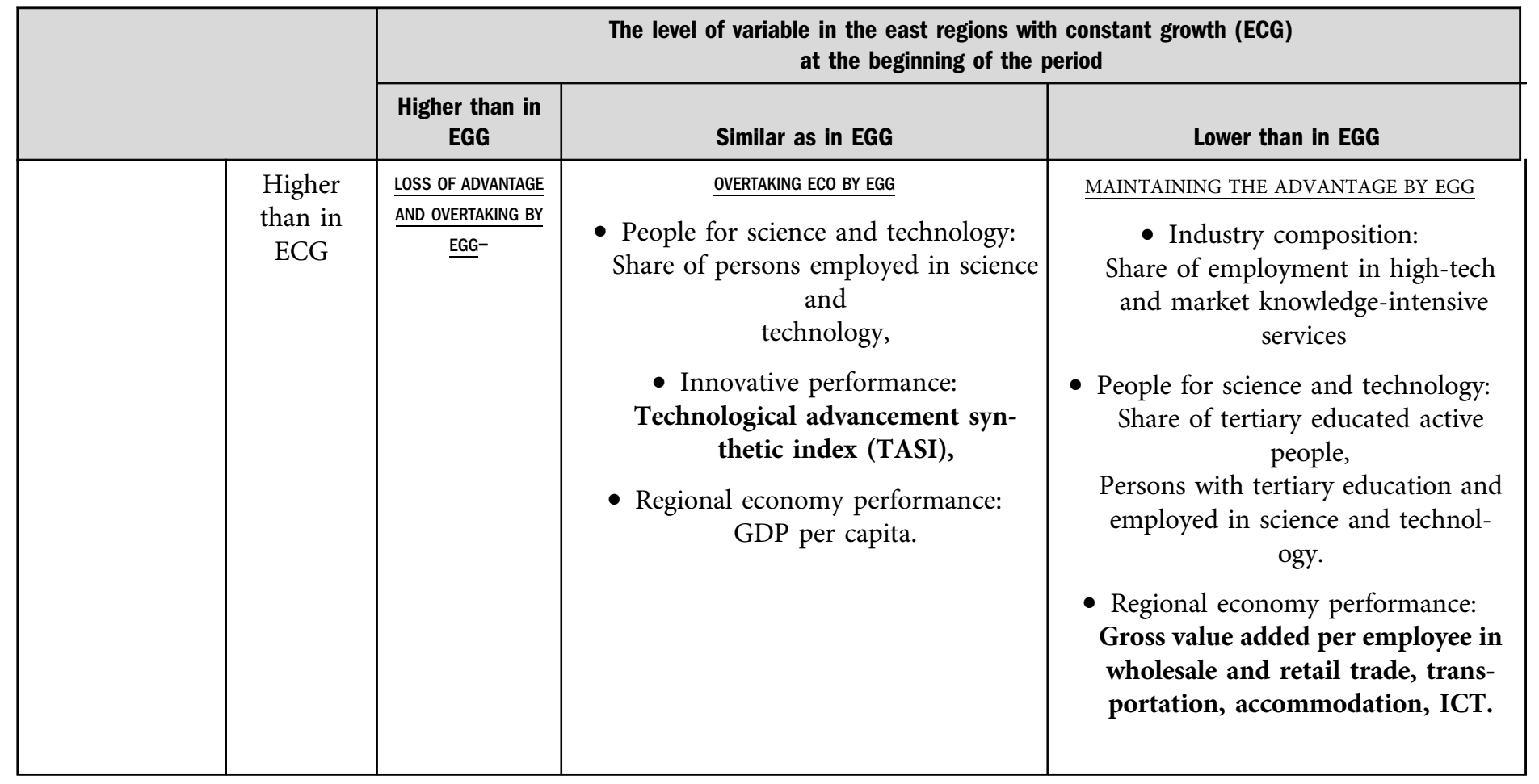

Source: Own elaboration based on Eurostat data.

Note: Bold font indicates GDP growth factors and underlined font indicates factors hampering GDP growth (see Table 3). 
and other services, and business density. The latter factor is caught up by the openness of the region and external markets. Also, increasing compensation of employees and gross fixed capital formation is pointless as they hamper GDP growth. However, the negative influence of compensation of employees should be explained in the subsequent studies.

The eastern regions at the beginning of transition should have a comparative advantage in possessing tertiary educated active people, including those employed in science and technology. Although this comparative advantage does not influence GDP growth, it supports (together with R\&D expenditure and high-tech knowledge-intensive services) technology advancement which impacts GDP growth. Technology advancement supports increase of productivity in the service sector which also impacts GDP growth. Therefore, increasing the share of service industries, especially high-tech and market knowledge-intensive services is crucial for successful transition despite the fact that the share itself does not influence GDP growth but indirectly develops the base for increasing productivity. In contrast to the western regions, business density reflecting urbanisation of economies and market size is crucial for GDP growth and should be supported within development policy. Also contrary to the western regions, gross fixed capital formation is crucial for growth which can be explained by the need of technology transfer via machines and equipment supply. In turn, similar to the western regions, the share of medium-high-tech industries is crucial for GDP growth. Interestingly, the eastern regions should increase employment rate of females due to the fact that it is one of the factors generating GDP.

\section{CONCLUSIONS}

The aim of the paper was to identify differences in determinants of successful transition between the eastern and the western European regions in the last two decades. We hypothesised that successful transitions require constructing regional advantages (Hypothesis H1) but the way of constructing these advantages differ across the regions (Hypothesis H2). We confirmed that both groups of the fast-growing regions constructed regional advantages because they changed comparative advantage into competitive advantage, entailing GDP growth. Interestingly, during construction of the advantages, both groups of the regions took various development paths indicated in our theoretical dynamic model. Both groups used knowledge-related factors to expand regional specialisation in the knowledge-intensive industries. Thus, these findings confirm both auxiliary hypotheses $\mathrm{H} 1 \mathrm{a}$ and $\mathrm{H} 1 \mathrm{~b}$. What is more, we proved that the construction of regional advantages significantly differs across the regions, which confirms Hypothesis $\mathrm{H} 2$.

The western regions had comparative advantage based more on $\mathrm{R} \& \mathrm{D}$ expenditure, people employed in science and technology, and patent applications, while the eastern regions were more focused on tertiary educated active people, including those employed in science and technology. The latter regions were specialised at the beginning of the period in high-tech and market knowledge-intensive services and gained an overwhelming increase in productivity in the service sector, contrary to the findings of Hausmann - Klinger (2007) stating that the initial specialisation does not translate to productivity increase. In turn, the western fast-growing regions were able to construct successful regional advantage through specialisation in both knowledge-intensive manufacturing and service sectors and increasing productivity in both sectors, confirming the findings of Asheim - Boschma et al. (2011). However, increasing 
productivity could only be possible during the analysed period thanks to the use of knowledge resources and innovations, which were a comparative advantage.

Both the western and the eastern fast-growing regions gained advantage over other regions only in the case of productivity in the service sector and only this productivity influenced GDP growth positively, which confirms the findings of Desmarchelier et al. (2013). At the same time, development of manufacturing industries cannot be discarded despite the fact that increase of productivity in manufacturing industries does not cause GDP growth. We confirmed that growth is created by increasing the share of medium-high-tech industries (but not high-tech, which confirms the findings for the less-developed regions of Pylak - Majerek (2014a)) in the economy in both the western and the eastern regions, mostly because these industries are customers of knowledge-intensive service providers (Consoli - Elche-Hortelano 2010), and thus, constitute a key element of the value chain. In the eastern regions there is also a need to invest in fixed capital which still facilitates additional technology transfer. In turn, the western regions worsen GDP growth by investing in fixed capital because the productivity level can no longer be increased by purchasing new equipment and the money spent is not intended to increase innovativeness and productivity effectively.

Our research confirms the significant role of technology advancement in constructing the regional advantage. Both the composite indicator and part of the component indicators are the key factors of GDP growth, which is in line with the neoclassical and new growth theories (Solow 1988; Romer 1986). In addition, an important role of the increase of the government's share in $R \& D$ expenditure was also confirmed in all regions.

The foundations of policies on constructing regional advantages, elaborated in the article, should be important for both scientists and policymakers, although the majority of the conclusions are well known. However, so far it has not been known, firstly, under what conditions and surroundings the specific factors would work, and secondly, how their combination will affect the individual elements of the competitive advantage created. We see that some factors have a negative effect in some regions, while in others they are strongly positive. Therefore, further study is necessary of the constructed regional advantages, in a larger lens, for example through case studies of regions experiencing rapid growth (see e.g. Wojnicka-Sycz 2018). It would also be important to study the medium-high-tech industries and knowledge-intensive services to determine the mechanism of increasing productivity and impact on GDP growth in the shorter and longer periods of time.

The western regions with constant growth should run a policy in respect of building technological and R\&D potential with the promotion of tertiary-level education and an educated workforce in different industries, especially in the medium high-tech industries. Moreover, the potential of the female workforce should be enhanced. These regions are often well equipped in capital goods, indicating high automatization and well-paid employees working usually in the highly specialised jobs such as programming. Increasing the rate of the tertiary-educated workforce should lower the costs, introducing more competitiveness to the labour market; and thus, more employees could reinforce the growth of Industry 4.0 and sophisticated services. Then, lower labour costs would increase the income of the companies, and thus, the GDP level.

The eastern constant-growing regions should build their potential through investments in capital goods and physical assets (referring to knowledge creation, assimilation and exploitation), being the base for the competitive advantage. These regions should also increase innovative potential and strengthen the academic centres so as to avoid the migration of educated 
people disappointed with the lack of technologically advanced manufacturing and service companies in the neighbourhood. Strengthening academia should induce technological entrepreneurship and attract technologically oriented domestic and foreign investors requiring specialised employees who cost less in those regions and are often more available than in the developed regions. As a result, more advanced jobs would yield higher wages, and thus, higher GDP, including higher regional demand.

The western growing regions should maintain a competitive position in terms of technological advancement and spill their technologies over to the less advanced industries, making Industry 4.0 possible. Then, it will be possible to produce goods in the advanced industries of those regions and not in other countries characterised by lower costs. A qualified workforce should be able to work in the Industry 4.0 factories as programmers or managers and in related service industries to produce sophisticated products based on ICT-driven design and delivery processes.

The eastern regions with high growth rates should further increase the amount and quality of tertiary-level education, and thus, improve the labour force working in science and technology, leading to building competitive advantage in respect of technological advancement, as in the western growing regions. A better workforce will also allow developing high-tech industries further and reducing the disadvantage of weak knowledge-intensive services, compared to the western growing regions. These measures would also induce high wages and seize the middleincome trap in these regions.

Our recommendations thus focus on the development of growth factors and competitive advantages of knowledge and technology in all of the types of the European regions, albeit stressing different aspects depending on the development level of these regions. These recommendations are crucial in the knowledge-based economy of the 21st century, which is increasingly based on ICT and automation and a highly educated workforce able to cope with high technology.

\section{ACKNOWLEDGEMENTS}

The research received funding from the National Science Centre, Poland under the Programme grant $n^{\circ}$ DEC-2014/13/B/HS5/03612. The grant was awarded to the University of Warsaw, Faculty of Geography and Regional Studies.

\section{REFERENCES}

Ades, A. F. - Glaeser, E. L. (1999): Evidence On Growth, Increasing Returns, and the Extent of the Market. Quarterly Journal of Economics, 114(3): 1025-1045.

Asheim, B. - Boschma, R. - Cooke, P. (2011a): Constructing Regional Advantage: Platform Policies Based on Related Variety and Differentiated Knowledge Bases. Regional Studies, 45(7): 893-904.

Asheim, B. - Moodysson, J. - Tödtling, F. (2011b): Constructing Regional Advantage: Towards State-ofthe-Art Regional Innovation System Policies in Europe? European Planning Studies, 19(7): 1133-1139. 
Becker, W. - Saisana, M. - Paruolo, P. - Vandecasteele, I. (2017): Weights and Importance in Composite Indicators: Closing the Gap. Ecological Indicators, 80: 12-22.

Boschma, R. (2015): Towards an Evolutionary Perspective on Regional Resilience. Regional Studies, 49(5): 733-751.

Cameron, A. C. - Trivedi, P. K. (2009): Microeconometrics Using Stata. College Station, TX: Stata Press.

Capello, R. - Nijkamp, P. (2009): Handbook of Regional Growth and Development Theories. Cheltenham: Edward-Elgar.

Consoli, D. - Elche-Hortelano, D. (2010): Variety in the Knowledge Base of Knowledge Intensive Business Services. Research Policy, 39(10): 1303-1310.

Csiki, O. - Horváth, R. - Szász, L. (2019): A Study of Regional-Level Location Decision Factors in the Automotive Industry of the EU. Acta Oeconomica, 69(S2): 11-37.

Dạbrowska, A. (2017): Determinants and Barriers in the Process of Changing the Development Path of the German Region of Brandenburg. In: Dziemianowicz, W. - Pylak, K. - Szlachta, J. (eds.): Kreślone innowacjami ścieżki rozwoju regionów słabiej rozwiniętych. Warsaw: Studia KPZK PAN Tom CLXXIX.

Desmarchelier, B. - Djellal, F. - Gallouj, F. (2013): Knowledge Intensive Business Services and Long Term Growth. Structural Change And Economic Dynamics, 25: 188-205.

Friedmann, J. - Weaver, C. (1977): Territory and Function: The Evolution of Regional Planning Doctrine. Los Angeles, CA: University of California.

Greene, W. H. (2003): Econometric Analysis. Upper Saddle River, NJ: Prentice Hall.

Hausmann, R. - Klinger, B. (2007): The Structure of the Product Space and the Evolution of Comparative Advantage. CID Working Paper, No. 146.

Hirschman, A. O. (1958): The Strategy of Economic Development. New Haven: Yale University Press.

Keynes, J. M. (1936): The General Theory of Employment, Interest and Money. Basingstoke and Hampshire: Palgrave Macmillan.

Kitson, M. - Martin, R. - Tyler, P. (2004): Regional Competitiveness: An Elusive Yet Key Concept? Regional Studies, 38(9): 991-999.

Lengyel, B. - Szakálné Kanó, I. (2014): Regional Economic Growth in Hungary 1998-2005: What Does Really Matter in Clusters? Acta Oeconomica, 64(3): 257-285.

Lucas, R. E. (1988): On the Mechanics of Economic Development. Journal of Monetary Economics, 22(1): 3-42.

Martin, R. - Sunley, P. (2015): Towards a Developmental Turn in Evolutionary Economic Geography? Regional Studies, 49(5): 712-732.

McFadden, D. (1974): Conditional Logit Analysis of Qualitative Choice Behavior. In: Zarembka, P. (ed.): Frontiers in Econometrics. New York: Academic Press, pp. 105-142.

Myrdal, G. (1968): Asian Drama: An Inquiry into the Poverty of Nations. New York: Pantheon.

Nishioka, S. (2013): R\&D, Trade in Intermediate Inputs, and the Comparative Advantage of Advanced Countries. Journal of the Japanese and International Economies, 30: 96-110.

OECD (2008): Handbook on Constructing Composite Indicators: Methodology and User Guide. Paris.

Perroux, F. (1950): Economic Space: Theory and Applications. The Quarterly Journal of Economics, 64(1): 89-104.

Peszat, K. - Szlachta, J. (2017): The Economic Openness of Lower Silesia as an Opportunity to Change the Region's Development Path. In: Dziemianowicz, W. - Pylak, K. - Szlachta, J. (eds.): Kreślone innowacjami ścieżki rozwoju regionów słabiej rozwiniętych. Warsaw: Studia KPZK PAN Tom CLXXIX.

Porter, M. E. (1990): The Competitive Advantage of Nations. Harvard Business Review, 68(2): 73-93. 
Porter, M. E. (1998): Clusters and the New Economics of Competition. Harvard Business Review, 76(6): 77-90.

Pylak, K. (2015): Changing Innovation Process Models: A Chance to Break Out of Path Dependency for Less Developed Regions. Regional Studies, Regional Science, 2(1): 46-72.

Pylak, K. - Majerek, D. (2014a): Regional Context in Technology Transfer and Patents Inducing Growth: Structural Models for More- and Less-Developed Regions. In: Gómez Chova, L. - López Martínez, A. - Candel Torres, I. (eds): ICERI2014 Proceedings. 7th International Conference of Education, Research and Innovation. Seville: IATED Academy, pp. 5735-5745.

Pylak, K. - Majerek, D. (2014b): Why Should Support for Innovative Processes Differ Regionally? Are Less Developed Regions so Different? In: Löster, T. - Pavelka, T. (eds): 8th International Days of Statistics and Economics. Conference Proceedings. Prague: Libuše Macáková, MELANDRIUM, pp. 1254-1264.

Pylak, K. - Wojnicka-Sycz, E. (2017): Transforming Innovation Models in European Regions: Breaking out of Path Dependency and Growing Faster? Miscellanea Geographica, 21(2): 51-59.

Recher, V. - Kurnoga, N. (2017): European Integration Perspectives: From Cohesion to Divergence? Acta Oeconomica, 67(2): 195-214.

Ricardo, D. (1817): On the Principles of Political Economy and Taxation. London, UK: John Murray, Albemarle-Street.

Romer, P. M. (1986): Increasing Returns and Long-Run Growth. Journal of Political Economy, 94(5): 1002-1037.

Santos-Vijande, M. L. - Lopez-Sanchez, J. A. - Gonzalez-Mieres, C. (2012): Organizational Learning, Innovation, and Performance in KIBS. Journal of Management \& Organization, 18(6): 870-904.

Schumpeter, J. A. (1912): Theorie der Wirtschaftlichen Entwicklung. Leipzig: Verlag von Duncker Humblot.

Schumpeter, J. A. (1934): The Theory of Economic Development: An Inquiry into Profits, Capital, Credit, Interest, and the Business Cycle. Cambridge, MA: Harvard University Press.

Smith, A. (1776): An Inquiry into the Nature and Causes of the Wealth of Nations. Dublin: Whitestone.

Solow, R. M. (1988): Growth Theory and After. The American Economic Review, 78(3): 307-317.

Strambach, S. (2008): Knowledge-Intensive Business Services (KIBS) as Drivers of Multilevel Knowledge Dynamics. International Journal of Services Technology and Management, 10(2/4): 152-174.

Uppenberg, K. - Strauss, H. (2010): Innovation and Productivity Growth in the EU Services Sector. Luxembourg: European Investment Bank.

Wintjes, R. - Hollanders, H. (2010): The Regional Impact of Technological Change in 2020. Report to the European Commission, Directorate General for Regional Policy, on Behalf of the Network for European Techno-Economic Policy Support ETEPS AISBL. Http://Ec.Europa.Eu/Regional_Policy/Sources/ Docgener/Studies/Pdf/2010_Technological_Change.Pdf.

Wojnicka-Sycz, E. (2013a): Growth Pole Theory as a Concept Based on Innovation Activity Development and Knowledge Diffusion. Research on Enterprise in Modern Economy Theory and Practice, pp. 17-33. Wojnicka-Sycz, E. (2013b): Model Terytorialnego Bieguna Wzrostu Jako Systemu Czynnikow Rozwojowych (The Model of Territorial Growth Pole as a System of Development Factors). University of Gdansk.

Wojnicka-Sycz, E. (2018): The Successful Transition to a Knowledge-Based Development Path of a LessDeveloped Region. Growth and Change, 49(3): 569-589.

Young, A. A. (1928): Increasing Returns and Economic Progress. The Economic Journal, 38(152): 527-542. Zukauskaite, E. - Moodysson, J. (2016): Multiple Paths of Development: Knowledge Bases and Institutional Characteristics of the Swedish Food Sector. European Planning Studies, 24(3): 589-606. 